\title{
9 The preparations for the first Chinese People's Political Consultative Conference and the quest for legitimacy
}

\author{
Henrike Rudolph
}

\section{Introduction}

A sheet of paper in his hand, his head slightly tilted, an array of microphones in front and his most loyal supporters behind, red lanterns swaying overhead. The image of Mao Zedong's proclamation of the founding of the People's Republic is ingrained in public memory. The festivities on October 1, 1949, marked the beginning of a new era in Chinese history with cheering masses and a military parade. The founding ceremony (kaiguo dadian 開國大典) was, however, not only a show of force of the Chinese Communist Party (CCP) and the People's Liberation Army. The line of supporters standing shoulder to shoulder with CCP leaders on Tian'anmen Gate embodied the promise of political stability and an inclusive government. ${ }^{1}$ Among them were eminent figures such as Shen Junru 沈鈞儒 (18751963), Zhang Lan 張瀾 (1872-1955), Song Qingling 宋慶齡 (1893-1981), and Li Jishen 李濟深 (1885-1959) as representatives of several left-leaning smaller parties and associations that had formed during the Republican period (1912-1949). Under the direction of the CCP's United Front Work Department (tongzhanbu 統戰部), they had laid the groundwork for the convening of a new political body, the Chinese People's Consultative Conference (CPPCC), in September 1949.

The CPPCC modeled its corporatist structure and function on Republican precursors to draw intellectuals and political activists into the Communist system of government. By inviting left-leaning elites to join the bridge-building process during the turbulent months of dissolution and reconstruction in 1948-1949, the CCP heralded an era of "New Democracy" (xin minzhu 新民主). Democracy, a term that had pervaded Mao's writings for years, now had to be filled with concrete meaning. The first CPPCC's preparations, however, were as much a process of inclusion as of exclusion and a preemptive move to stifle demands for a genuinely democratic form of government.

The pomp and circumstance of the enraptured masses and the military parade on October 1 outshone the preceding ceremonies of the first CPPCC. Likewise, in historical scholarship, the preparations for the CPPCC have received little attention, mainly because historians tended to dismiss it as mere political theatre. Gerry Groot has offered the most comprehensive analysis to this day, but his focus rests on the events themselves, not, for example, their portrayal in contemporary

DOI: $10.4324 / 9781003158608$ 
media. ${ }^{2}$ This chapter thus revisits the months preceding the first CPPCC and focuses on the following three points: first, it takes the symbolism of the first CPPCC seriously and reconsiders its role in strategically constructing an image of the CCP's popular support. Second, it will bring the public perception of the preparations leading up to the first CPPCC to the fore, arguing that the rehearsal was just as important as the performance itself. Third, the first CPPCC is examined as part of a more significant endeavor to create a coherent foundation myth of the People's Republic of China (PRC). These three issues are central to our understanding of the narrative of a "New Democracy," which constitutes a fundamental source of legitimacy of the PRC's system of government until today. ${ }^{3}$

\section{Changing visions of legitimate rule in the republican period}

Before we can turn to the events leading up to the convening of the first CPPCC in September 1949, we have to revisit the attempts to form similar advisory bodies during the preceding two decades. Only then can we grasp the historical significance and the symbolic deviations from previous attempts to use consultative bodies for the expansion of regime legitimacy.

From the last decades of the nineteenth century to the end of the Republican period, Chinese perceptions of the relationship between the individual, the collective, and the state witnessed dramatic change. Former subjects of imperial rule now laid claim to their rights and duties as citizens. These changes became most apparent in discourses on citizenship and nationalism, the emergence of new public institutions, and a new education system. ${ }^{4}$ Progressive intellectuals examined foreign political alternatives as members of study societies or joined forces in nationalist organizations and political parties. ${ }^{5}$ Moreover, an increasingly selfconfident urban workforce made their demands heard through protests, boycotts, and strikes. Such mass movements of the early Republican period further paved the way for more popular modes of forming and expressing political opinions and the emergence of mass political parties in the mid-1920s. ${ }^{6}$ However, how exactly the will of the masses was to enter political decision-making processes was a contested issue.

Early experiments with popular voting had proven in the eyes of many observers that "elections merely aggregated private interests, which could be manipulated by unscrupulous campaigners for personal benefit." ${ }^{\text {"7 }}$ Nonetheless, even though the elites were divided on the question of popular voting, they united behind the demand for a greater involvement of intellectuals and experts as counsels to the government, which was firmly in the hands of the Nationalist Party (Guomindang 國民黨, GMD). They believed that their expertise would improve political decision-making and that they could act as mediators between the government and the common people's interests. The self-image of many intellectuals, their trust in the moral character of talented men, and the primacy of a strong government over civil liberties were reminiscent of the justification of merit-based appointments for political offices during the late imperial period. In 1931, the GMD government gave in to the intellectuals' demands as its reputation decreased with every 
concession to Japanese aggression. They extended an invitation to prominent public figures (except Communists) to join a National Emergency Conference (Guonanhui 國難會), which met in Luoyang in April 1932. ${ }^{8}$

Contemporary critics unmasked the conference as a mere political gesture to counter a growing sense of disillusionment caused by the empty promises of an inclusive and representative form of government and the related loss of legitimacy. After the disclosure of the list of participants, the famous intellectual Tao Xingzhi 陶行知 (1891-1946) derided it as a “celebrity conference" (mingren huiyi 名人會議), in which fame outranked expertise. None of the participants ever fended for themselves through manual labor, but they would still claim to speak on behalf of China's common people (dai laobaixing shuohua 代老百姓說話). "The deterioration of politics in recent years stems from this word dai. ... How I wish that this grievous word will no longer be included in future dictionaries of the Chinese Republic," Tao concluded reproachfully. ${ }^{9}$ Other prominent figures like Shi Liangcai 史量才 (1880-1934) joined the call for a boycott of the National Emergency Conference. They demanded to replace it with an assembly of real political influence, yet the GMD was not willing to put its monopoly of power up for discussion. ${ }^{10}$ Even GMD delegates voiced concerns over the lack of representative bodies as a counterweight to one-party rule. ${ }^{11}$

In 1938, the GMD started a renewed attempt to appease calls for a more democratic form of government by establishing the Guomin canzhenghui 國民參政會, the "National Political Participatory Assembly." Again, the real power of the council did not meet expectations. Peng Juyuan 彭菊園 (dates unknown) described the longing for structures that would represent the will of the people (minyi jiguan 民意機關). In Peng's view, a genuinely democratic council would have to meet four criteria: first, it would need to be large enough to represent the diversity of China's large population; second, its members would have to be selected through democratic procedures; third, it would have to hold the highest decision-making power; and fourth, participation in this council should be open to people from all parts of China. ${ }^{12}$ The National Political Participatory Assembly fell short in all four points. However, we see here the yardstick for measuring later proposals for consultative or even legislative assemblies: size, elective procedures, legal status, and the representation of all regions and social groups.

With the Japanese defeat and the end of the Second World War, the external threat's unifying power diminished, and the GMD's and CCP's competition for popular support entered a new round. In 1945, the American and Soviet governments pressured both parties to return to the negotiation table and to sign the "Double Tenth Agreement"13 on October 10. As part of this agreement, a Political Consultative Conference (Zhengzhi xieshang huiyi 政治協商會議) was to be held as the first step toward the drafting of a constitution and a reformed united government, including the so-called democratic parties and groups (minzhu dangpai 民主黨派, DPGs). ${ }^{14}$ However, when the conference finally convened in January 1946, the government had failed to implement the necessary reforms promised in the agreement. Not surprisingly, the public expectations of the conference merely ranged from cautiously optimistic to fatalistic. ${ }^{15}$ Already the concluding 
celebrations of the consultative conference were disrupted by attacks on DPG representatives. Both $\mathrm{CCP}$ and GMD refocused on solving the conflict through the power of the gun rather than persuasion.

Ultimately, the failure of the GMD to make political concessions, as well as the persecution of DPG members, helped the Communists to portray themselves as a conciliatory force pressured into a military confrontation. As Lyman van Slyke noted, at this point, the language of CCP propaganda changed accordingly from an "anti-feudal united front," to a "new democratic united front," reaching its climax in an even broader "anti-Chiang front" against the head of the GMD government Chiang Kai-shek蔣介石 (1887-1975). ${ }^{16}$ Furthermore, the CCP began to set up elected representative bodies in the areas under their control to showcase their willingness to cooperate across party divisions. ${ }^{17}$ In short, the CCP decided to revive the "old" consultative conference (jiu zhengxie 舊政協) of 1946 not because it had been a functioning political body but, on the contrary, as a potent symbol of democratic promises broken by the GMD, which were finally to be realized by the CCP with a "new" consultative conference (xin zhengxie 新政協). The choice of the name "consultative conference" rather than, for example, "participatory council" (canzhenghui 參政會) projected an image of a transitional assembly that was to mediate between political forces and to pave the way for a new form of government. That this body would become a permanent part of the PRC's political system was not apparent at this stage.

\section{Legitimizing Communist rule}

With the decision to grant the CPPCC - and thereby the minor political parties and nonaligned intellectuals - an official status within the state apparatus, the CCP leadership broke with the model of the Soviet Union. Years earlier, Mao Zedong had coupled the ideal of an inclusive constituency with a Marxist avantgarde leadership in his writings on "New Democracy." For him, historical materialism and scientific communism justify the rule of the working class led by the Communist Party over the people. Following this logic, the working classes, commanded by party members, possess the highest level of social consciousness and are thus the driving force in the linear historical progress toward socialism and communism. This role as a vanguard of historical change legitimizes party authority, while the power of the state rests on the claim that it represents the interests of the people. ${ }^{18}$

In Communist China, the oxymoron of the "people's democratic dictatorship," a term Mao coined in 1949, exemplifies this logical friction between the rule of the few and the will of the masses. Only the Communist Party, he declared, possessed the necessary knowledge and foresight to create a glorious classless future. Under the leadership of the CCP, the masses (minzhong 民眾) could unite and rise up to create a democracy for the people (renmin 人民) and a dictatorship for the reactionaries (fandongpai 反動派). ${ }^{19}$ Accordingly, the only relevant bestowers of legitimacy are the masses. All those who refuse to follow the CCP are counterrevolutionaries and hence irrelevant to the construction of legitimacy. ${ }^{20}$ 
It was not Mao, however, who first put the theory of a Communist-led "people's democracy" into practice. After the Second World War, the "new democracies" of Eastern Europe set precedents for alternatives to the Soviet state system. ${ }^{21}$ By inviting all toilers to participate in a (nominal) coalition government, they established a much more inclusive policy than the Soviet "dictatorship of the proletariat." 22 When the CCP leadership decided that China too would follow a path independent of the Soviet model, they invoked special historical conditions.

The popular democratic dictatorship in China includes representatives and political groups of the liberal bourgeoisie which wish to fight imperialism, feudalism, and bureaucratic capital. This is the difference [from the Soviet Union]. This circumstance is explained by the fact that China is a semi-colonial country and that in a period of revolution and after its victory, we will need for a long time a concentration of all the forces in the fight against imperialism and its agents. ${ }^{23}$

Mao's principle of a people's democratic dictatorship is only the normative dimension of the construction of the legitimacy of CCP rule. A shared belief in the logic and truth of Marxist theories is the precondition for its acceptance. Yet, in the transition period of the late 1940s, a large part of China's elites still embraced a vision of legitimacy based on constitutionalism, deliberation, and inclusiveness. Because there was not a unified "Legitimitätsglaube" (belief in legitimacy) in a Weberian sense, ${ }^{24}$ the new regime could not solely rely on ideological persuasiveness. David Beetham identifies three different factors that are essential for creating a belief in legitimacy. First, "the legal validity of the acquisition and exercise of power," second, "the justifiability of the rules governing a power relationship in terms of the beliefs and values current in the given society," and third, "the evidence of consent derived from actions expressive of it," such as political rituals. ${ }^{25}$ Even nondemocratic rulers "need to credibly anchor their legitimacy claim in the hearts and minds of the people." ${ }^{26}$ Hence, after the abolition of the "old" political system in 1949, the CCP needed a new narrative of how this regime not only received an ex-post approval but also how it was created through consensual deliberations between Communist and non-Communist leaders.

In short, as the proclamation of the People's Republic drew closer, the planning for the CPPCC was part of the Communists' strategy to tie the normativeideological legitimation of power and the popular belief in legitimacy together. All of China and the world were watching how the CCP would "set the stage" for the CPPCC. ${ }^{27}$ Every official communiqué, every gesture of goodwill toward the DPGs, and every negotiation report contributed to the stabilizing of CCP rule during the transition period. The CCP later combined these narrative threads and memorialized them as part of a political myth of the founding of the People's Republic. Christopher Flood's understanding of political myth as "an ideologically marked narrative which purports to give a true account of a set of past, present, or predicted political events and which is accepted as valid in its essentials by a social group" 28 is instructive in this respect. How exactly the events leading 
up to the first CPPCC unfolded and whether we can glimpse behind the scenes of the "ideologically marked narrative" will be discussed in the following section.

\section{Inviting the protagonists and setting the stage}

With its historical baggage of the "old" consultative conference, the reconvening of a "new" conference became a political tightrope act: if the CCP convened a meeting before it could be sure that DPG representatives would participate, it would lose face. Furthermore, the convening of a consultative conference before military victory was within reach would undermine the historical significance of the event, which could then no longer serve as a prelude to the institutionalization of the new government. Mao thus hesitated to proclaim the founding of the PRC before strategic locations, such as the Beiping (Beijing) and Nanjing, had come under CCP control. ${ }^{29}$ On the other hand, if the CCP waited too long, the Americans might pressure the GMD to reconvene a consultative conference driving a wedge between the Communists and the intellectuals and DPGs. From early 1948 onward, the CCP began to stage a process of planning and consultation by forming a "Preparatory Committee of the New Consultative Conference" (Xin zhengxie choubei hui 新政協籌備會). They hoped to bring the DPGs to commit themselves publicly in support of a CCP-led government prior to the founding of the PRC.

With the "Labor Day Call” (Wu yi kouhao 五一口號) on May 1, 1948, the CCP extended a formal invitation to all peasants, workers, and Chinese youth of the "freedom movement" (ziyou yundong 自由運動) as well as the intellectuals, the "free capitalist class" (ziyou zichan jieji 自由資產階級), the DPGs, prominent public figures (shehui xianda 社會賢達), ${ }^{30}$ and all other patriots to participate in the formation of a "Democratic United Government" (minzhu lianhe zhengfu 民主聯合政府). ${ }^{31}$ The CCP, however, refrained from directly naming people or groups in the call, thereby giving the impression of being open for cooperation with all political forces that could commit to anti-imperialism, anti-feudalism, anti-bureaucratic capitalism, and the fight against Chiang Kai-shek. Cosignatories of this appeal were, among others, leaders of the Revolutionary Committee of the Chinese Guomindang (Zhongguo guomindang geming weiyuanhui 國民黨革命委員會), the Chinese Democratic League (Zhongguo minzhu tongmeng 中國民主同盟), the National Salvation Association (Jiuguohui 救國會), and the Zhigong Party (Zhigongdang 致公黨). ${ }^{32}$

Interestingly, the cosignatories vanished from most official PRC historiographies. ${ }^{33}$ In 1949, the image of a concerted effort of the CCP and smaller political parties lent credibility to the call for creating a united government. Today, the mentioning of other parties chips away some of the glory that the CCP claims for its vanguard spirit in promoting a "New Democracy." Yet, even in official narratives that omit the cosignatories, the CCP remains a convener and arbiter, not a controller of events and a symbol that by publicly endorsing the call, the DPGs implicitly accepted CCP leadership. However, as Groot has pointed out:

[T] the support of MPGs [DPGs] did not necessarily mean unqualified endorsement for all CCP policies or its ultimate program. What the MPGs 
[DPGs] failed to realize was that the CCP was going to transform them to suit its new agenda. ${ }^{34}$

By 1948, the CCP had already infiltrated or cooped some of the DPGs, diminishing their independence. ${ }^{35}$ Yet up until today, the Labor Day Call is a central element of the CCP's construction of legitimacy. ${ }^{36}$

Not all of those responding to the Labor Day Call were already influential political forces. A response to the call could also elevate small associations that had previously been politically insignificant to a level of national importance. As A. Doak Barnett rightfully predicted in December 1948,

the alliance of these splinter groups in Hong Kong with the Communist Party lifted the names of their leaders from relative obscurity to prominence in the seething rumor markets of present-day China. ... It is probable, therefore, that some time next year press dispatches and other reports of developments in China will contain the names of many political parties, groups, and leaders in China that heretofore have been virtually unknown, even to many people within their own country. ${ }^{37}$

The assembling of figures that might not all be famous, but representative, for example, of China's scholars, scientists, teachers, or business people, might not have hurt the cause of projecting representativeness. Broad strata of Chinese society that felt marginalized by the Communist rhetoric of class struggle should identify with these delegates, and thereby another "celebrity conference" could be avoided. Overall, the CCP narrative of an enthusiastic response of all progressive forces and notable Chinese intellectuals to the Labor Day Call has to be called into question.

Once left-leaning DPG leaders had publicly endorsed the Labor Day Call, the ball was in the playing field of the CCP again. Yet the Communists waited another three months until they reacted to the endorsement. In August 1948, Mao Zedong invited a carefully selected group of 55 DPG representatives and "democrats" (minzhu renshi 民主人士) to the areas under CCP control to initiate the consultations for the establishment of a united government. Initially, the CCP had planned to convene the consultative conference by autumn in Harbin, but the military situation changed dramatically during the summer of 1948 . When the Communist forces advanced quicker than expected, the consultative conference was rescheduled to coincide with the proclamation of a new government. ${ }^{38}$ To uphold the image of a busy preparation process until a military victory was secured, the CCP finally brought prominent figures, for example, the writer Mao Dun 茅盾 (alias Shen Dehong 沈德䲨, 1896-1981) and his wife Kong Dezhi 孔德沚 (1897-1970), Li Jishen of the Revolutionary Committee of the Chinese Guomindang, ${ }^{39}$ as well as Shen Junru of the Chinese Democratic League, to the "liberated areas."

By involving a maximum number of political activists in this streamlined process, the Communists killed three birds with one stone: first, by inviting these 
prominent figures to the areas under their control, the CPP could shield them from the influence of their opponents. As Mao Zedong lamented in December 1948:

Now the Americans ... sent their diplomatic workers and journalists to the leaders of the right-wing of the democratic league - Luo Longji, Zhan[g] Lan, Hua Nanshe, and to the leader of the revolutionary committee of the Guomindang Li Jishen (he is en route to the liberated areas), so as to conduct among them provocative work and efforts to lure [them in]. We already paid attention to this and must do our best to make sure that the Americans will not achieve the aim of their intrigue. ${ }^{41}$

Indeed, when GMD member Huang Shaohong 黃紹竑 (1895-1966) flew to Hong Kong in January 1949 to convince Li Jishen to come to Nanjing and act as a mediator between the GMD and the CCP, he arrived only to find that Li had left days earlier. ${ }^{42} \mathrm{Li}$ and the other prominent figures, among them the political activists Zhu Yunshan 朱蘊山 (1887-1981) and Peng Zemin 彭澤民 (1877-1956), who secretly boarded a cargo ship for Dalian in December 1948, felt they were no longer safe in Hong Kong. The CCP's offer to smuggle those political leaders persecuted by the GMD out of the city was thus hard to decline. Once the group arrived in Dalian, Zhou Enlai 周恩來 (1898-1976) personally arranged a fine hotel, a banquet, and even a new set of clothes against the harsh Northern winter. ${ }^{43}$

Second, the CCP leadership was eager to prove that they took the concerns of the smaller parties seriously and organized inspection tours, study sessions, and called for informal discussions. In a speech to fellow CCP cadres, Dong Biwu 董必武 (1886-1975), who had been involved in the consultations, concluded in August 1949 that when they had published the Labor Day Call in May 1948 to convene the consultative conference, the DPGs still embraced diverse views. Contested issues were especially the leadership status of the CCP, the possibility of peace with the GMD, China's dependency of the United States and Great Britain, and reservations against the Soviet Union. ${ }^{44}$ In their meetings with the visiting intellectuals, the CCP put such questions as the continuation of class struggle after the Communist victory, ${ }^{45}$ the decision on how a "democratic" political system could look like, and which role the DPG leaders would take in the new government up for discussion. ${ }^{46}$ These exchanges offered a platform for the probing of common ground and the honing of arguments. In other words, in the early months of 1949, the CCP tested the ideological toolkit that they continued to employ after 1949 to convince China's intellectual elites of the CCP's rightful rise to power.

And third, the sojourn of the DPG leaders in the model communes of the "liberated areas" held a propagandistic value. Intellectuals like Zhang Bojun 章伯鈞 (1895-1969) or Shen Junru possessed a valuable social and cultural capital that enabled them to communicate effectively with social groups beyond the Communists' reach. Writings of Li Jishen, Shen Junru, and Zhang Bojun from the year 1948 illustrate how these political thinkers reframed the plans for a new consultative conference in a way that resonated more with the Republican elites than 
the anti-capitalist or anti-bureaucrat slogans of the Communist camp. Li, speaking for the Revolutionary Committee of the Chinese Guomindang, reinterpreted the political writings of Sun Yat-sen (Sun Zhongshan 孫中山, 1866-1925) and claimed that the CCP's proposal of convening a consultative conference was in accordance with Sun's demands for representative institutions. Sun was revered across the political spectrum as an icon of the revolution of 1911, and the article thus invoked his name to construct a sense of shared political ideals of all forces opposed to the GMD's one-party dictatorship. ${ }^{47}$ Shen Junru similarly distanced himself from the GMD and reminded his readers that to hope for creating peace with the GMD was just as hopeless as trying to "fish for the moon in the water." 48 And in an article Shen coauthored with Zhang Bojun, both drew a line in the sand between democracy and dictatorship, as well as between the people and the people's enemies. They embraced the call for a new consultative conference as the only remaining road to a democratic, peaceful, and united "New China." Everyone not on their side was a reactionary working against the interest of the people. ${ }^{49}$ Without explicitly endorsing Communist ideology, or even praising the military or political achievements of the CCP, all of these writings stressed the moral decay of the GMD. These intellectuals thus achieved what would have been impossible for Communist writers, which is to shift the attention away from the potential danger of a new one-party rule under a Communist regime and to decouple the call for a reconvening of a consultative conference from all ideological questions that separated the DPGs and the CCP.

The second type of publications that disseminated from Northern China were reports on the administrative and political situation in the Communist-ruled areas. Sun Qimeng 孫起孟 (1911-2010), a member of the China National Democratic Construction Association (Minzhu jianguohui 民主建國會), for example, stressed that life was like heaven in comparison to the hell of the GMD-held territories and praised the humanistic spirit of the correctional facilities he had visited in Harbin. ${ }^{50}$ Fifty-five visitors to the "liberated areas" voiced their support for the political strategy of Mao Zedong in a statement they published in several journals such as the Haitao 海濤 in Shanghai and Hong Kong's journal Gonglun 公論, a mouthpiece of the Zhigong Party. ${ }^{51}$ In the version that appeared in the Haitao, however, an entire paragraph praising an "atmosphere of democratic freedom," the exemplary conduct of CCP cadres, and the neat and rapid reconstruction of social and economic order was missing. ${ }^{52}$ Apparently, the subversive force and the discursive power of this paragraph were forceful enough to necessitate censorship in Shanghai.

Despite their recurring references to democratic principles and appraisals for the rule of law, the publications disseminating from the CCP territories were, at the same time, very frank in their portrayal of the CCP's understanding of democracy. In a lengthy article, Sun Qimeng discussed how he came to realize that he and his fellow intellectual friends needed to reform their thinking and to better themselves for the service of the people (and thereby the CCP), and he denounced all opposing forces as reactionary. ${ }^{53}$ Furthermore, these publications spelled out in no uncertain terms what the CCP expected from intellectuals in general and the DPGs in particular. Like the DPG's public vows of support following the Labor Day Call, 
these publications thereby contributed to a narrative of a conscious and unhesitant submission of China's minor political forces to CCP leadership in the months preceding the founding of the People's Republic. Additionally, in these writings, the DPG leaders themselves undermined any future challenges to CCP's legitimacy by labeling all forces questioning the Communist leadership as revisionist.

Newspaper coverage from the GMD-ruled areas countered the CCP's United Front Work Department's tale of harmonious and unanimous consultations. It scolded the intellectuals and their DPGs, who had followed the invitation to the "liberated areas," as victims of false promises. Luo Jianbai 羅堅白 (dates unknown) of the Chinese Democratic Socialist Party (Zhongguo minzhu shehuidang 中國民主社會黨) ridiculed those leaving for the "liberated" areas as opportunists trying to hunt down a government post "like ants drawn to rotten meat, like flies in pursuit of a foul smell." ${ }^{54}$ The New Statesman (Xin zhengzhijia 新政治家) similarly denounced the theatrical "beating of gongs and drums for the new consultative conference," declaring that all those who still hoped the conference would be a continuation of the peace talks of 1946 were misguided. The article quotes extensively from CCP documents to prove that the CCP had, in fact, no interest in engaging with all parties and certainly not on an equal footing. ${ }^{55}$ Similarly, the journal Life and Time (Shenghuo yu shidai 生活與時代) questioned the CCP's attempt to convene a consultative conference consisting of small parties that were in no way representative of the general Chinese population. If they wanted a more inclusive government, why not merely hold a popular election? Yet, the coverage of the preparations for the consultative conference not only questioned the "democratic" motives of the CCP, but it also painted a picture of an exasperated GMD that resorted to both promises and intimidations to keep prominent political figures from joining the conference. ${ }^{56}$

Overall, the Chinese public was left to speculate for many months as to where the conference would assemble, who was to participate, and whether it would negotiate peace between the GMD and CCP or herald a new political regime. The Communist leadership, due to the rapidly changing national and international political situation and out of security concerns, set no definite date or place. Thus, making a virtue of necessity, Mao Zedong still claimed in the telegram to the DPG representatives that the opportune timing of convening the assembly, its location, and the decision who to invite was not yet set because it should rest in the hands of the democratic leaders to reach a joint decision on these issues. ${ }^{57}$

In late 1948, before a formal Preparatory Committee for the New Consultative Conference assembled, there were effectively three hubs of activity: the first was the CCP's United Front headquarter in Lijiazhuang, where Zhou Enlai hosted some of Beijing's prominent intellectuals like Fu Dingyi 符定一 (1877-1958), Wu Han 吳晗 (1909-1969), and Liu Qingyang 劉清揚 (1894-1977); the second was the Northeastern Bureau of the CCP in Harbin, where the CCP cadres Gao Gang 高崗 (1905-1954) and Li Fuchun 李富春 (1900-1975) conferred with DPG leaders Shen Junru, Tan Pingshan 譚平山 (1886-1956), Zhang Bojun, and others who had arrived from Hong Kong in September 1948; the third was the network of political allies remaining in Hong Kong. ${ }^{58}$ In the following months, 
drafts, comments, and revisions were sent back and forth between these three locations. ${ }^{59}$ Unfortunately, the paper trail that these deliberations must have left behind has to this day not been made public. Nonetheless, the available sources allow us to reconstruct the haggling over the size and composition of the CPPCC. Here again, the symbolic dimension is not only reflective of reality, but it also constituted reality: the list of factions invited to the CPPCC became a barometer registering who gained or lost favor with the $\mathrm{CCP}$ in the following months.

\section{Delegations in the CPPCC}

The formal planning process of the first CPPCC began with a draft by Zhou Enlai titled "Various Questions Concerning the Convening of a New Political Consultative Conference" (Guanyu zhaokai xin de zhengzhi xieshang huiyi zhu wenti 關於召開新的政治協商會議諸問題). Unfortunately, all official CCP source collections omitted Zhou's draft. Most other documents drafted and revised during the preparations for the consultative conference are also kept under lock and key. ${ }^{60}$ Thus, changes in the available invitation lists can give important insights into power struggles between the DPGs and the CCP as well as between the DPGs that competed for influence in the new regime.

A list attached to the CCP leadership's draft from October 1948 mentioned 39 entities: 9 DPGs, 6 factions representing local interests, 6 factions representing the military as well as representatives from 17 civic associations. ${ }^{61}$ Already one week later, the number of DPGs had shrunken to seven, excluding the Zhigong Party and the Democratic National Construction Association. ${ }^{62}$ The final "Agreement on Questions Concerning the Convening of a New Political Consultative Conference," published on November 25, 1948, listed 23 entities that were to dispatch up to 4 delegates (see Table 9.1).

In considering the list's symbolic importance, let us turn first to its composition. On closer inspection, an apparent division between the table's upper and lower part reflects two different conceptions of representation (and thereby of legitimacy). Even though the participants were never elected by a public vote or in a transparent intraparty process, the CPPCC stressed the "representativeness" (daibiaoxing 代表性) of this assembly. The upper part catered to Republicanera conceptions of a representation of competing political forces, such as in the Anglo-American system. The lower section, with its delegations of women, ethnic minorities, and students, illustrates the CCP's corporatist approach to representation resting on the assumption that women best represent women, members of ethnic groups best represent ethnic minorities, and so forth. After 1949, the DPGs were subjected to the same corporatist logic of representation when the CCP set clear guidelines for noncompetitive membership recruitment that was limited to specific constituencies. They assigned DPGs and other political organizations the function of transmission belts communicating with and supervising predetermined social groups. Shielded from the public eye, the DPGs included in this list had already come under a varying degree of CCP influence by late 1948 and were after 1949 transformed into corporatist structures. ${ }^{64}$ 
Table 9.1 Groups of Participants of the CPPCC as Listed in the "Agreement on Questions Concerning the Convening of a New Political Consultative Conference" 63

\begin{tabular}{|c|c|c|}
\hline No. & Name Chinese (Pinyin) & English \\
\hline 1 & 中國共產黨 (Zhongguo gongchandang) & Communist Party of China \\
\hline 2 & $\begin{array}{c}\text { 中國國民黨革命委員會 (Zhongguo } \\
\text { guomindang geming weiyuanhui) }\end{array}$ & $\begin{array}{l}\text { Revolutionary Committee of the } \\
\text { Chinese Guomindang }\end{array}$ \\
\hline 3 & $\begin{array}{l}\text { 中國民主同盟 (Zhongguo minzhu } \\
\text { tongmeng) }\end{array}$ & Chinese Democratic League \\
\hline 4 & $\begin{array}{l}\text { 中國民主促進會 (Zhongguo minzhu } \\
\text { cujinhui) }\end{array}$ & $\begin{array}{l}\text { Chinese Association for Promoting } \\
\text { Democracy }\end{array}$ \\
\hline 5 & 中國致公黨 (Zhongguo zhigongdang) & Chinese Zhigong Party \\
\hline 6 & $\begin{array}{l}\text { 中國農工民主黨 (Zhongguo nonggong } \\
\text { minzhudang) }\end{array}$ & $\begin{array}{l}\text { Chinese Workers' and Peasants' } \\
\text { Democratic Party }\end{array}$ \\
\hline 7 & $\begin{array}{l}\text { 中國人民救國會 (Zhongguo renmin } \\
\text { jiuguohui) }\end{array}$ & Chinese People's Salvation Association \\
\hline 8 & $\begin{array}{c}\text { 中國國民黨民主促進會 (Zhongguo } \\
\text { guomindang minzhu cujinhui) }\end{array}$ & $\begin{array}{l}\text { Chinese Guomindang Association for } \\
\text { the Promotion of Democracy }\end{array}$ \\
\hline 9 & $\begin{array}{l}\text { 三民主義同志聯合會 (Sanmin zhuyi } \\
\text { tongzhi lianhehui) }\end{array}$ & $\begin{array}{l}\text { Federation of Comrades of the Three } \\
\text { Principles of the People }\end{array}$ \\
\hline 10 & 民主建國會 (Minzhu jianguohui) & $\begin{array}{l}\text { Democratic National Construction } \\
\text { Association }\end{array}$ \\
\hline 11 & $\begin{array}{l}\text { 無黨派民主人士 (Wu dangpai minzhu } \\
\quad \text { renshi) }\end{array}$ & Democrats without party affiliation \\
\hline 12 & 全國教授 (Quanguo jiaoshou) & Professors \\
\hline 13 & 國內少數民族 (Guonei shaoshu minzu) & National minorities \\
\hline 14 & $\begin{array}{l}\text { 海外華僑民主人士 (Haiwai huaqiao } \\
\quad \text { minzhu renshi) }\end{array}$ & Chinese democrats living overseas \\
\hline 15 & $\begin{array}{c}\text { 中華全國總工會 (Zhonghua quanguo } \\
\text { zonggonghui) }\end{array}$ & All-China Workers' Union \\
\hline 16 & $\begin{array}{l}\text { 解放區農民團體 (Jiefangqu nongmin } \\
\text { tuanti) }\end{array}$ & $\begin{array}{l}\text { Peasants' associations in the liberated } \\
\text { areas }\end{array}$ \\
\hline 17 & $\begin{array}{l}\text { 全國婦女聯合會籌備委員會 } \\
\text { (Quanguo funü lianhehui choubei } \\
\text { weiyuanhui) }\end{array}$ & $\begin{array}{l}\text { Preparatory Committee of the All- } \\
\text { China Women's Federation }\end{array}$ \\
\hline 18 & $\begin{array}{l}\text { 全國學生聯合會 (Quanguo xuesheng } \\
\text { lianhehui) }\end{array}$ & $\begin{array}{l}\text { All-China Federation of Student } \\
\text { Unions }\end{array}$ \\
\hline 19 & $\begin{array}{l}\text { 全國青年聯合會籌備委員會 } \\
\text { (Quanguo qingnian lianhehui } \\
\text { choubei weiyuanhui) }\end{array}$ & $\begin{array}{l}\text { Preparatory Committee of the All- } \\
\text { China Youth Federation }\end{array}$ \\
\hline 20 & $\begin{array}{l}\text { 上海人民團體聯合會 (Shanghai } \\
\text { renmin tuanti lianhehui) }\end{array}$ & $\begin{array}{l}\text { Federation of People's Organizations in } \\
\text { Shanghai }\end{array}$ \\
\hline 21 & $\begin{array}{l}\text { 產業界民主人士 (Chanyejie minzhu } \\
\text { renshi) }\end{array}$ & Democrats from industrial circles \\
\hline 22 & $\begin{array}{l}\text { 文化界民主人士 (Wenhuajie minzhu } \\
\text { renshi) }\end{array}$ & Democrats from cultural circles \\
\hline 23 & $\begin{array}{l}\text { 中國人民解放軍 (Zhongguo renmin } \\
\text { jiefangjun) }\end{array}$ & People’s Liberation Army \\
\hline
\end{tabular}


Second, the order of the DPGs in the upper part of the list is of importance. Up until today, official documents maintain a particular order in listing the DPGs, reflecting a political hierarchy. ${ }^{65}$ When the preparatory committee officially met for the first time on June 19, 1949, the order of the participating parties and groups had changed again. For example, the Democratic National Construction Association had risen to the 4th position, while the Zhigong Party descended to the 11 th position. ${ }^{66}$ In the sources, the underlying rules for setting this hierarchy are opaque. Yet, four factors were central: the ideological proximity of the DPGs to the Communist Party, the public image of the parties' most influential members, the direct involvement in the consultation process in Lijiazhuang or Harbin, as well as the importance of the constituents that each DPG could mobilize for the national reconstruction.

Here again, the May First Call was of strategic significance in the construction of the consultative conference's and thereby the CCP's legitimacy. To deflect allegations that the CCP was not interested in a united government but would merely pick close allies and weak parties excluding all contesting forces, the CCP claimed that hierarchies apparent in the listings merely reflected how quickly the DPGs had responded to the call for holding a consultative conference in May 1948. ${ }^{67}$ To attentive observers, however, not only the shifting order of DPGs in these lists but also the conspicuous absence of certain parties must have called this narrative into question.

The Chinese Association for the Promotion of Popular Education (Zhonghua pingmin jiaoyu cujinhui 中國平民教育促進會), the Chinese Peasants' Party (Zhongguo nongmindang 中國農民黨), the Guangfu Association (Guangfuhui 光復會), the Chinese Young Workers' Party (Zhongguo shaonian laodongdang 中國少年勞動黨), the Alliance for People's Freedom and Democracy (Renmin minzhu ziyou lianmeng 人民民主自由聯盟), and other political parties and associations requested to participate in the CPPCC. Yet, the CCP claimed that members of those groups were mostly reactionaries, and thus their request was declined. Selected members willing to readjust their political views could nonetheless return to the "people's camp" and "participate in the construction of a New China." 68

The Chinese Democratic Socialist Party (Zhongguo minzhu shehuidang 中國民主社會黨) was a more complicated case. Under the leadership of Zhang Junmai 張君勱 (1987-1969), the Democratic Socialists had joined the "old" consultative conference of 1946, and Zhang continued to cooperate with the GMD in drafting a new constitution. This caused an intraparty rift because many members had become wary of the authoritarian rule of the GMD and, by 1947, founded the Reform Faction of the Democratic Socialist Party (Minshedang gexinpai 民社黨革新派). ${ }^{69}$ Its leaders Sha Yankai 沙彥楷 (1875-1970) and Wang Shiming 汪世銘 (1896-1977) had responded to the May First Call on behalf of the Reform Faction. ${ }^{70}$ Therefore, according to a logic one might call "whoever is willing to join will be invited," the Minshedang gexinpai should have participated in the CPPCC. In June 1949, the preparatory committee for the CPPCC decided that they would not reward seats to the party because their political stance was 
unclear. Nonetheless, Sha and Wang were offered memberships in the Chinese Democratic League, and the Reform Faction of the Democratic Socialist Party disbanded. ${ }^{71}$ In a report to I. V. Stalin, the CCP's Central Committee member Liu Shaoqi commented on the DPG's structure:

In each democratic party and group there are several leaders who have some influence among the popular masses, thanks to their having engaged in political activity in China for a long time. Their party organizations are held together only in these leaders. There are three categories of people in each party and group: rightists, leftists, and centrists. ${ }^{72}$

Thus, as long as one could integrate the most prominent leftist or centrist leaders into the CPPCC, the DPGs as organizational structures were no longer important. The Jiusan Study Society (Jiusan xueshe 九三學社), on the other hand, never counted more than a hundred members before 1949 and was nonetheless included in the CPPCC, representing university teachers and scientists. Its name was only added to the list of participating groups in June $1949,{ }^{73}$ which exemplifies how the CPPCC embraced tiny organizations like the Jiusan or the Taiwan Democratic Self-Government League (Taiwan minzhu zizhi tongmeng 台灣民主自治同盟). They expanded only after the founding of the PRC into organizational strongholds that served to reach certain parts of the Chinese elites.

In short, the publication of the different lists demonstrated the broadness and strength of the new united front. They proved that the first CPPCC concluded a process that had effectively separated the democratic forces of the Republican period into two camps, leading to the successful exclusion, weakening, or even disbanding of political associations. It elevated some groups to a level of national importance not founded on popular support but rather on corporatist functions that these parties had to fulfill within the united front framework.

\section{The preparatory committee of the consultative conference}

After the takeover of Beijing in January 1949, the United Front Work Department could finally relocate to the new capital. They selected the Beijing Hotel (Beijing fandian 北京飯店) and the Liuguo Hotel (Liuguo fandian 六國飯店), two of the most luxurious hotels in the city, for a liaison office. The office's task was to make life as pleasant as possible for those political figures who had participated in the initial consultations in Lijiazhuang, Harbin, and other parts of the country and who now gathered in Beijing. The head of the United Front Work Department, Li Weihan 李維漢 (1896-1984), regularly invited the DPG representatives to socalled tea meetings (chahui 茶會) to the Liuguo Hotel. Additionally, Mao Zedong and Zhou Enlai personally met with the DPG leaders to discuss national and international questions. ${ }^{74}$ As we do not have detailed accounts of these meetings, it is unclear whether the participants were encouraged to express their opinions on the convening of the CPPCC or the reorganization of China's cultural, social, and political institutions or if these meetings were merely study sessions intended to 
teach them Mao's doctrine of a "People's Democratic Dictatorship." Furthermore, from April to June, a group of nearly 60 prominent figures from the DPGs, overseas Chinese, cultural, and literary circles, as well as from different classes and minorities of Chinese society, went on a study tour to the Northeastern cities. Li Weihan and his colleagues ensured that the DPG leaders led a comfortable life in Beijing and that their children had access to a good education. They should feel that the CCP still valued their cooperation and be kept busy until the Preparatory Committee for the CPPCC first convened on June 11, 1949, at the residence of Mao Zedong in Xiangshan (Beijing). ${ }^{75}$

By July 1949, Mao Zedong proudly reported to Moscow that the convening of a preparatory committee had already been a success. It appeased the democratic forces while ensuring CCP control over all proceedings:

The democratic and unaffiliated public figures are quite satisfied with such a method of convening the PCC [Political Consultative Conference].... It [the preparatory committee] has 134 members, of which 43 are Communists, 48 are progressive figures who will unquestionably support us, 43 centrists, but 12 of which are centrists with a rightist inclination. There are 15 among the progressive figures who are clandestine Communists. Leadership in the Preparatory Committee is furnished by the Communist Party. A permanent presidium of 21 people has been created in the Preparatory Committee. Leadership in this presidium has also been furnished by the Communist Party. ${ }^{76}$

Among those who Mao considered "clandestine Communists" might have been, for example, Zhang Bojun and Tan Pingshan. Zhang and Tan had joined the CCP in the early 1920 s but left the party after the Nanchang Uprising in $1927 .{ }^{77}$ They were officially known as leaders of the Chinese Workers' and Peasants' Democratic Party, but rumors of Zhang's concealed CCP membership or at least close cooperation with CCP cadres were rampant in $1947 .{ }^{78}$ By the late 1940 s, the fact that the CCP was covertly recruiting leaders of the DPGs or even installing CCP members in strategic positions was an open secret. ${ }^{79}$

Despite the CCP's growing control over the DPG structures and even though they had only invited handpicked individuals to enter the preparatory committee, Mao nonetheless feared that the GMD might infiltrate the DPGs or even convene a rivaling consultative conference under GMD auspices. ${ }^{80}$ On the surface, however, an atmosphere of confidence and friendship was to be maintained. In the opening speech of the first meeting of the preparatory committee, Mao Zedong reiterated that, apart from the "enemies of the people" (imperialists, feudalists, bureaucratic capitalists, and reactionary GMD), "we are all friends, we are all one large and strong revolutionary united front." ${ }^{81}$ In his speech, Mao even refrained from using the rhetoric of CCP leadership over all other parties and groups.

The preparatory committee proceeded to form six workgroups, each being in charge of a specific task: group 1 determined the list of associations and groups to participate in the CPPCC and their delegates (headed by Li Weihan), group 2 drafted the statutes for the CPPCC (head: Tan Pingshan), group 3 outlined 
the "Common Program" as a provisional government program of the PRC (head: Zhou Enlai), group 4 prepared the organic law of the Central People's Government (head: Dong Biwu), group 5 wrote the official declaration of the first CPPCC (head: Guo Moruo 郭沫若, 1892-1978), and group 6 was to reach a decision concerning the national flag, the national emblem, and the national anthem (head: Ma Xulun 馬敘倫, 1885-1970). Thus, official (not clandestine) CCP party members headed the workgroups and relegated DPG leaders like Huang Yanpei 黃炎培 (1878-1965) or Xu Deheng 許德街 (1890-1990) to vicehead positions. ${ }^{82}$ The staged organizing of six groups and public haggling over the composition of the CPPCC were part of the CPP's attempt to at least formally meet the criteria observers expected of "democratic" assemblies (as outlined above): a large number of delegates, some form of elective procedures with delegates dispatched by the parties, a real decision-making power, and a diversity of representatives that would reflect China's social, regional, and ethnic diversity.

The discussion over the name of the new state exemplifies that even though the CCP allowed an exchange of views, no final decision could be reached against the CCP's will. While the members of the Preparatory Committee Huang Yanpei and Zhang Zhirang 張志讓 (1893-1978) advocated for the name "People's Democracy of China” (Zhonghua renmin minzhuguo 中華人民民主國), Zhang Xiruo (張奚若, 1889-1973) favored “People's Republic of China” (Zhonghua renmin gongheguo 中華人民共和國). The term “people's republic” would already invoke the notion of democratic rule. ${ }^{83}$ The CCP's resistance against the inclusion of the word minzhu 民主 in the state name was symptomatic of how they understood "New Democracy" to refer to a transitory period, rather than a long-term commitment. Gradually the term "democratic" also vanished, for example, from the name of the All-China Women's Federation, which used the name All-China Democratic Women's Federation (Zhonghua quanguo minzhu funü lianhehui 中華全國民主婦女聯合會) until 1957. ${ }^{84}$

In sum, from the perspective of the DPGs, the preparatory committee already cemented the pattern of participation without independent decision-making power that later characterized their work in the CPPCC. The committee and its workgroups concluded their work on September 20, one day before the People's Liberation Army fired a salute outside the Huairen Hall in Beijing and thereby ceremoniously heralded the successful convening of the CPPCC. The People's Daily, as the mouthpiece of the new government, reported extensively on the proceedings, interviewed the delegates and recorded their speeches, and featured pictures showing the members on stage behind microphones or as an attentive audience. Other photographs showed Beijing citizens parading the streets with banners welcoming the CPPCC. ${ }^{85}$ The Xinhua broadcasting service of Beijing additionally recorded and broadcasted the speeches for a larger audience. ${ }^{86}$

\section{Conclusion}

In the late 1940s, the CCP's strategy of tying as many political forces as possible to the regime profited from gravitational forces that drove intellectuals and 
political activists away from the GMD to the left. Many political activists were appalled by the GMD's lack of respect for the rule of law, and GMD persecution forced some to seek refuge in the "liberated areas", while others awaited the arrival of a new government in Hong Kong. Dissatisfaction with the GMD did not, however, turn directly into support of the Communists. The CCP hence went to great lengths to make cooperation attractive. Having by 1948 or 1949 to choose between the tutelage of either one of the mass parties (GMD or CCP), many political activists chose the latter, because the $\mathrm{CCP}$ at least seemed to make an effort to consider different voices. The CCP rhetoric of "New Democracy" and the temporary deemphasizing of class struggle helped to meet those who were skeptical of Communist ideology halfway.

Once political figures had arrived in the CCP-ruled territories, the CCP successfully shielded them from GMD influence. It drove a wedge between the democratic movement and made DPG leaders and their families financially and politically dependent on the new regime. Simultaneously, just as it severed ties to "reactionary forces," the preparatory committee forged new relationships between members of different DPGs and nonaligned political figures by bringing them together in regular meetings bridging previous party boundaries. Behind the scenes, the months of preparation and "rehearsal" of the first CPPCC thus bore fruit in eliminating or isolating any influential voices in the public discourse that could have challenged the narrative of a peaceful assumption of power of the CCP. On the public stage, by convening the CCPCC as a revival of a Republicanera institution, the CCP upheld the promises for a legal multi-party rule that the GMD had broken. To believe, however, that the DPGs were blindly following a trace of honey only to fall into the CCP's totalitarian trap is unfounded. The media coverage of the time gave voice to both ardent supporters of the Communist revolution as well as well-informed calls of warning. For many of the later CPPCC delegates, their alliance with the Communists must have been a strategic decision to secure a political office.

To reach a conclusive answer as to how exactly the preparations and the CPPCC itself provided a foundation for a popular belief in legitimacy (Legitimitätsglaube), we should revisit Beetham's three foundations of legitimacy. The gradual institutionalization of consultative structures from discussion meetings to the preparatory committee, and finally to the drafting of laws governing the first CPPCC created the "legal validity of the acquisition and exercise of power." Second, the subordination of several DPGs to CCP leadership and the thereby implicit acceptance of Mao's theory of "People's Democratic Dictatorship" as well as the DPG leader's appraisals of life in the "liberated areas" contributed to "the justifiability of the rules governing a power relationship in terms of the beliefs and values current in the given society." And third, the strategy reached its peak when the staging of the CPPCC itself provided "the evidence of consent." ${ }^{87}$

Since 1949, the CCP yearly reconvenes the CPPCC as a televised proof of the government's popular support and its system of rule. Thus, it turned the united front policies, once designed to win over the forces of the middle during the civil war, into a strategy to stabilize the postwar order and a mythopoeic prehistory 
of the PRC. The legislative power of the CPPCC was gradually dismantled after 1949, and later generations were never again allowed to assume as many ministerial posts as the early DPG leaders. Nonetheless, even though the early CCP revolutionaries believed that the "New Democracy" phase and its institutions would only be maintained for a decade or two, 70 years later, the CPPCC is still meticulously restaged (by now in the symbol-laden Hall of the People on Tian'anmen square). In contrast, the preparatory process preceding the first CPPCC was in danger of sinking into oblivion. The production of the movie "The Founding of a Republic" (Jianguo daye 建國大業), starring a dazzling cast of 100 of China's biggest film stars, brought the narrative back to a new generation of citizens in 2009. For Sebastian Veg, the film sheds light on some recent trends in PRC historiography:

This commercial conceit also carries with it an implied ideological message: history, thus invaded by the contemporary star system, is no longer the province of the anonymous proletariat; turning away from Marxist methodology, the film portrays the founding of the PRC as a succession of intrigues and strategic moves by a well-defined set of great men (and a few women) led by Mao. The rural masses are to all intents and purposes swept off the stage of history. ${ }^{88}$

Gloria and M. E. Davies share Veg's assessment that this film is symptomatic of a change in official PRC historiography. ${ }^{89}$ As I would argue, however, the movie signifies not only a turning away from the "collective protagonist." 90 The more conciliatory stance to non-CCP political figures, the depiction of the DPGs leader's gradual rapprochement to the $\mathrm{CCP}$, as well as the extensive coverage of the work of the preparatory committee of the CPPCC that concludes the film is re-invoking narratives of peaceful cooperation that the Cultural Revolution had erased from public memory. Overall, the public discourse spurred by the movie, the recent reemphasis on united front work by President Xi Jinping, and the remodeling of the old site of the United Front Work Department in Shijiazhuang into a red tourism spot all exemplify that the legitimizing power of the PRC's foundation myth of consensual consultations and decision-making of 1948-1949 has gained in relevancy in the past decade..$^{91}$

\section{Notes}

1 The scene has been captured in numerous paintings and became a popular motif for propaganda posters, such as the famous painting by Dong Xiwen. See Yan Geng, Mao's Images: Artists and China's 1949 Transition (Wiesbaden: J.B. Metzler, 2018), 127-171.

2 Gerry Groot, Managing Transitions: The Chinese Communist Party, United Front Work, Corporatism, and Hegemony (New York: Routledge, 2004), 49-55.

3 Jean-Pierre Cabestan, "The Chinese People's Political Consultative Conference (CPPCC): Its Role and Its Future," in The EU-China Relationship - European Perspectives, ed. Kerry Brown (London: Imperial College Press, 2015), 51-62.

4 See, for example, Joseph Levenson, Confucian China and Its Modern Fate (Berkeley, CA: University of California Press, 1968); Prasenjit Duara, Rescuing History from the 
Nation (Chicago, IL: University of Chicago Press, 1995); Joshua A. Fogel and Peter Zarrow, Imagining the People (Armonk, NY: M.E. Sharpe, 1997); Thomas D. Curran, Educational Reform in Republican China (Lewiston, NY: Edwin Mellen Press, 2005); Robert Culp, Articulating Citizenship: Civic Education and Student Politics in SouthEastern China, 1912-1940 (Cambridge, MA: Harvard University Press, 2007); Peter Zarrow, After Empire: The Conceptual Transformation of the Chinese State, 18851924 (Stanford, CA: Stanford University Press, 2012).

5 Edmund S. K. Fung, "Recent Scholarship on the Minor Parties and Groups in Republican China," Modern China 20, no. 4 (1994): 478-508.

6 Shakhar Rahav, "Predicated on the People: Legitimating Mass Politics and Parties in Early Republican China," Cross-Currents: East Asian History and Culture Review 6, no. 1 (2017): 262-295.

7 Joshua Hill, Voting as a Rite: A History of Elections in Modern China (Cambridge: Harvard University Press, 2019), 162.

8 Edmund S. K. Fung, In Search of Chinese Democracy: Civil Opposition in Nationalist China, 1929-1949, Cambridge Modern China Series (Cambridge: Cambridge University Press, 2000), 88-96.

9 Tao Xingzhi 陶行知, “Guonan huiyi yu mingren huiyi” 國難會議與名人會議 [The National Emergency Conference and the Celebrity Conference], Shenbao 申報, January 28, 1932, 11.

10 Groot, Managing Transitions, 2.

11 Fung, In Search of Chinese Democracy, 91.

12 Peng Juyuan 彭菊園, “Ping guomin canzhenghui” 評國民參政會 [Assessing the National Political Participatory Assembly], Minzhu 民主 1, no. 1 (1938): 20-21. For earlier attempts to establish advisory political bodies in the late Qing and early Republican period, see the chapter by Egas Moniz Bandeira in this volume.

13 Also called "Minutes of the GMD-CCP Talks" (Guo Gong huitan jiyao 國共會談紀要).

14 Like Edmund Fung, Gerry Groot translates the minzhu dangpai as "minor parties and groups" (MPGs). Groot, Managing Transitions, xiii; Fung, "Recent Scholarship on the Minor Parties and Groups in Republican China." I have chosen the verbatim translation of "democratic parties and groups" (DPGs), not because I claim that they were democratic but because as symbols of a "new democracy" they are still relevant today. See also James D. Seymour, "China's Satellite Parties Today," Asian Survey 26, no. 9 (1986): 991.

15 Ruo Yu 若愚, “Cong jiantao Guo Gong huitan jiyao shuodao zhengzhi xieshang huiyi de qiantu” 從檢討國共會談紀要說到政治協商會議的前途 [Discussing the Future of the Consultative Conference in Light of the Minutes of the GMD-CCP Talks], Minzhu 民主, no. 5 (1946): 1.

16 Lyman van Slyke, Enemies and Friends: The United Front in Chinese Communist History (Stanford, CA: Stanford University Press, 1967), 189.

17 Groot, Managing Transitions, 18.

18 Georg Brunner, "Legitimacy Doctrines and Legitimation Procedures in East European Systems," in Political Legitimation in Communist States, eds. Thomas Harold Rigby and Ferenc Fehér (Oxford: Macmillan: St. Antony's College, 1982), 30-32.

19 Mao Zedong 毛澤東, “Lun renmin minzhu zhuanzheng”論人民民主專政 [On the People's Democratic Dictatorship], in Lun renmin minzhu zhuanzheng xuexi cankao cailiao 論人民民主專政學習參考材料, ed. Duzhe shudian 讀者書店 (Tianjin: Duzhe shudian, 1949), 7.

20 On the construction of legitimacy of leaders within the CCP, see Frederick C. Teiwes, Leadership, Legitimacy, and Conflict in China: From a Charismatic Mao to the Politics of Succession (Armonk, NY: M.E. Sharpe, 1984).

21 H. Gordon Skilling, "People's Democracy, the Proletarian Dictatorship and the Czechoslovak Path to Socialism," American Slavic and East European Review 10, no. 2 (1951): 100-116; Benjamin Schwartz, "China and the Soviet Theory of People's Democracy," Problems of Communism 3, no. 5 (1954): 8-15. 
22 Ruth Amende Rosa, "The Soviet Theory of 'People's Democracy,' "World Politics 1, no. 4 (1949): 495.

23 Liu Shaoqi, "Report from the Head of the Delegation of the $\mathrm{CC}$ of the Chinese Communist Party, 'The Current State of the Chinese Revolution'," trans. Gary Goldberg, July 4, 1949, RGASPI, f. 558, op. 11, d. 328, 11. 32-50, History and Public Policy Program Digital Archive, https://digitalarchive.wilsoncenter.org/document/1 34156.

24 Max Weber, Economy and Society (Berkeley, CA: University of California Press, 1987), 213.

25 David Beetham, The Legitimation of Power (New York: Palgrave Macmillan, 2013), $12-13$.

26 Johannes Gerschewski, "Legitimacy in Autocracies: Oxymoron or Essential Feature?" Perspectives on Politics 16, no. 3 (2018): 654.

27 Walter Sullivan, "China's Communists Set Stage to Form Coalition Regime," New York Times, June 20, 1949.

28 Christopher Flood, Political Myth: A Theoretical Introduction (London: Routledge, 2002), 44.

29 Anastas Ivanovich Mikoyan, "Memorandum of Conversation between Anastas Mikoyan and Mao Zedong," trans. Sergey Radchenko, January 31, 1949, APRF: F. 39, Op. 1, D. 39, Ll. 7-16, History and Public Policy Program Digital Archive, https://di gitalarchive.wilsoncenter.org/document/112436.

30 The CCP dropped the term shehui xianda 社會賢達 in 1949, because it was too closely associated with those intellectuals who had participated in the National Assembly (Guomin dahui 國民大會) under the GMD government. After some of these prominent figures such as Wu Yunwu and Fu Sinian had followed the GMD to Taiwan, the CCP instead began to adopt the expression “democrats” (minzhu renshi 民主人士), or “patriotic democrats" (aiguo minzhu renshi 愛國民主人士) when referring to those anti-GMD intellectuals who did not belong to any political party. Shaanxi zhengjiaoxi bianxiezu 陝西師大政教系編寫組, Zhongguo Gongchandang lishi 中國共產黨歷史 [History of the Chinese Communist Party] (Chang'an: Shaanxi shida zhengjiaoxi, 1980), 237; Dong Biwu 董必武, Dong Biwu zhengzhi falü wenji 董必武政治法律文集 [Collected Political and Legal Works of Dong Biwu] (Beijing: Falü chubanshe, 1986), 59.

31 Reprinted in: Zhongguo minzhu tongmeng zhongyang wenshi ziliao weiyuanhui 中國民主同盟中央文史資料委員會, ed., Zhongguo minzhu tongmeng lishi wenxian 1941-1949 中國民主同盟歷史文獻1941-1949 [Historical Documents of the Chinese Democratic League 1941-1949] (Beijing: Wenshi ziliao chubanshe, 1983), 419-421.

32 Doak Barnett, China on the Eve of the Communist Takeover (New York: Praeger, 1963), 83.

33 See, for example, Ye Jiefu 葉介甫, “1949 nian xin zhengxie daibiao shi ruhe chansheng de" 1949年新政協代表是如何產生的 [How the New Political Consultative Conference's Delegates Were Nominated in 1949], Yanhuang chunqiu 炎黃春秋, no. 6 (2019): 41.

34 Groot, Managing Transitions, 58.

35 Groot, 20.

36 Liu Yandong 劉延東, ed., Lishi cong zheli kaishi - Jinian Zhongguo Gongchandang lingdao de duodang hezuo wu shi zhou nian 歷史從這裡開始紀念中國共產黨領導的多黨合作五十週年 [This Is Where the History Begins Commemorating the 50th Anniversary of the Chinese Communist Parties' Multi-Party Cooperation] (Beijing: Huawen chubanshe, 1999), 9.

37 Barnett, China on the Eve of the Communist Takeover, 83.

$38 \mathrm{Li} \mathrm{Ge}$ 李格, "Yi jie zhengxie choubei wenti de ruogan kaocha" 一屆政協籌備問題的若干考察 [Investigation into the Preparations for the Political 
Consultative Conference], Dangdai Zhongguo shi yanjiu 當代中國史研究 13, no. 4 (2006): 71-76. Some Chinese sources explain the delay with a disruption of communication channels so that the DPG's response only reached Mao Zedong three months later. However, that the CCP headquarters were during the summer of 1948 completely cut off from all communications seems less likely than a conscious decision to postpone. See, for example, Shu Yun 舒雲, “Zhengxie huiyi shang de quwen yishi” 政協會議上的趣聞軼事 [Interesting Anecdotes from the Consultative Conference], in Jianguo milu 建國秘錄, eds. Cao Ying 曹英 and Yu Minhui 余敏輝 (Beijing: Tuanjie chubanshe, 1993), 154.

39 Even though this political group still carried the name of the Guomindang, it had split from the Nationalists during the civil war and by the 1940s sided with the CCP.

40 Li Jishen 李濟深, “Yonghu Zhonggong baxiang tiaojian: Renmin minzhu geming bixu jinxing daodi” 擁護中共八項條件：人民民主革命必須進行到底 [In Support of the Eight Demands of the Communist Party - The People's Democratic Revolution Has to Be Carried Through to the End], Gonglun 公論, no. 5 (1949): 21-22.

41 Mao Zedong, "Cable, Mao Zedong to Stalin," trans. Sergey Radchenko, December 30, 1948, APRF: F. 39, Op. 1, D. 31, Ll. 49-52, History and Public Policy Program Digital Archive, https://digitalarchive.wilsoncenter.org/document/113789.

42 Li Peijin 李沛金, Wo de fuqin Li Jishen 我的父親李濟深 [My Father Li Jishen] (Beijing: Tuanjie chubanshe, 2007), 154.

43 Li Peijin, 162-64.

44 Dong Biwu, Dong Biwu zhengzhi falü wenji, 60.

45 Mao coined the slogan "carry the revolution through to the end" (jiang geming jinxing daodi 將革命進行到底) in December 1948 proclaiming that the CCP and its allies (including the DPGs) could not stop until they had smashed all traces of imperial exploitation, feudalism, or counterrevolutionary activities. Xinhuashe 新華社, Jiang geming jinxing daodi 將革命進行到底 (Beijing: Xinhua shuju, 1949), 5.

46 Sha Jiansun 沙建孫, ed., Zhongguo gongchandang tongshi 中國共產黨通史 [Comprehensive History of the Chinese Communist Party], vol. 5 (Changsha: Hunan jiaoyu chubanshe, 2000), 690-692.

47 Li Jishen 李濟深, “Zhongguo guomindang geming weiyuanhui - Duiyu xin zhengxie de yijian” 中國國民黨革命委員會—對於新政協的意見 [The Revolutionary Committee of the Chinese Guomindang - Views on the New Consultative Conference], Ziyou 自由, no. 8 (1948): 20-21.

48 Shen Junru 沈鈞儒, “Wo duiyu shiju kanfa” 我對於時局看法 [My Views on the Current Political Situation], Shidai piping 時代批評 5, no. 104 (1948): 7.

49 Shen Junru 沈鈞儒 and Zhang Bojun 章伯鈞, “Shiju shengming”時局聲明 [Statement on the Current Political Situation], Guangmingbao 光明報 2, no. 8 (1948): 2.

50 Sun Qimeng 孫起孟, “Ha’erbinshi jianyu canguanji” 哈爾濱市監獄參觀記 [Notes from a Visit to the Harbin Municipal Prison], Jinbu qingnian 進步青年, no. 1 (1949): $26-27,31$.

51 Li Jishen, "Yonghu Zhonggong baxiang tiaojian: Renmin minzhu geming bixu jinxing daodi"; "Li Jishen Shen Junru Zhang Bojun deng fabiao shiju yijian" 李濟深沈鈞儒章伯鈞等發表時局意見 [Li Jishen, Shen Junru, and Zhang Bojun Express Their Views on the Current Political Situation], Haitao 海濤, no. 5 (1949): 14.

52 "Li Jishen Shen Junru Zhang Bojun deng fabiao shiju yijian."

53 Sun Qimeng 孫起孟, "Wo duiyu zhishi fenzi gaizao de jidian renshi" 我對於知識分子改造的幾點認識 [Some Remarks on My Understanding of Reforming the Intellectuals], Jinbu qingnian 進步青年, no. 2 (1949): 5-7.

54 Luo Jianbai 羅堅白, “Guoshedang ruci 'zai fenlie'” 國社黨如此「再分裂」[So the National Socialist Party Is Divided Again], in Zhongguo minzhu shehuidang 中國民主社會黨, ed. Fang Qingqiu 方慶秋 (Beijing: Dang'an chubanshe, 1988), 506.

$55 \mathrm{Yu}$ Yuan 于遠, “Miluo jingu de xin zhengxie” 密鑼緊鼓地新政協 [The Beating of Gongs and Drums for the New Political Consultative Conference], Xin zhengzhijia 新政治家 1, no. 4 (1948): 3-6. 
56 One article mentions a rumor that the CCP first planned to hold the consultative conference in Hong Kong. It stated that it was only the British government's decision to expel the Communist activists from Hong Kong as a retaliation against the Soviet Union's Berlin Blockade that undermined this plan, yet this claim could not be substantiated from other sources. Wei Liang 維梁, "Rushi wo wen de xin zhengxie ji daji xin zhengxie de fangce" 如是我聞的新政協及打擊新政協的方策 [What I Heard of the New Consultative Conference and the Measures Taken against the New Consultative Conference], Shenghuo yu shidai 生活與時代 1, no. 6 (1948): 9.

57 Mao Zedong 毛澤東, “Mao Zedong guanyu zhaokai xin zhengxie fu ge minzhu dangpai dian”毛澤東關於召開新政協復各民主黨派電 [Telegram by Mao Zedong to the Minor Political Parties and Groups on Convening a New Consultative Conference], in Zhonggong zhongyangwenjian xuanji 中共中央文件選集, ed. Zhongyang dang'anguan 中央檔案館, 17 (1948) (Beijing: Zhonggong zhongyang dangxiao chubanshe, 1992), 273-74.

58 Ye Jiefu, "1949 nian xin zhengxie daibiao shi ruhe chansheng de."

59 Tong Xiaopeng 童小鵬, Yu Gang 于剛, and Yin Hua 尹華, “Guanyu choubei he zhaokai Zhongguo renmin zhengzhi xieshang huiyi de huiyi" 關於籌備和召開中國人民政治協商會議的回憶 [Recollection of the Preparations and Convening of the Chinese People's Political Consultative Conference], in Yinglai shuguang de shenghui - Xin zhengzhi xieshang huiyi qin liji 迎來曙光的盛會一 新政治協商會議親歷記, ed. Shi Guangshu 石光樹 (Beijing: Zhongguo wenshi chubanshe, 1987), 6 .

60 This draft is mentioned, for example, in Sun Xiaohua 孫曉華 and Sun Shizhong 宋士忠, eds., Fengyu tongzhou gandanqing 風雨同舟肝膽情 [A Heroic Spirit through Thick and Thin] (Beijing: Zhonggong zhongyang dangxiao chubanshe, 1995), 34.

61 According to Qin Lihai it included ten DPGs. Qin Lihai 秦立海, “1949 nian xin zhengxie choubei jishi” 1949年新政協籌備紀事 [Record of the Preparatory Work for the New Consultative Conference of 1949], Wenshi jinghua 文史精華, no. 183 (2000): 4.

62 Revolutionary Committee of the Chinese Guomindang (12 representatives), Chinese Democratic League (15), Chinese Association for Promoting Democracy (3), Chinese Workers' and Peasants' Democratic Party (6), National Salvation Association (7), Chinese Guomindang Association for the Promotion of Democracy (1), and the Federation of Comrades of the Three Principles of the People (8). "Ba ge minzhu dangpai de paixu shi ruhe queding de" 八個民主黨派的排序是如何確定的 [How the Sorting Order of the Eight Democratic Parties and Groups Was Determined], Renmin zhengxie wang 人民政協網, February 2, 2016, http://www.rmzxb.com.cn/c/2016-02-1 5/697897.shtml; Qin Lihai, "1949 nian xin zhengxie choubei jishi," 4.

63 Yang Jianxin 楊建新 and Shi Guangshu 石光樹, eds., "Guanyu zhaokai xin de zhengzhi xieshang huiyi wenti de xieyi” 關於召開新的政治協商會議問題的協議 [Agreement on Questions Concerning the Convening of a New Consultative Conference], in Wuxing hongqi cong zheli shengqi - Zhongguo remin zhengzhi xieshanghui dansheng 五星紅旗從這裡升起——中國人民政治協商會議誕生 (Beijing: Wenshi ziliao chubanshe, 1984), 212-214; Fung, "Recent Scholarship on the Minor Parties and Groups in Republican China," 482-483.

64 Groot, Managing Transitions, 20-27.

65 Zhang Xin 張听, “Ba ge minzhu dangpai paixu de youlai” 八個民主黨派排序的由來 [The Origins of the Sorting Order of the Eight Democratic Parties and Groups], Shidai youkan 時代郵刊, no. 7 (2019): 24-25.

66 Yang Jianxin 楊建新 and Shi Guangshu 石光樹, eds., “Guanyu canjia xin zhengzhi xieshang huiyi de danwei ji qi daibiao ming'e de guiding" 關於參加新政治協商會議的單位及其代表名額的規定 [On the Regulations Concerning the Groups and Their Quota of Representatives to the Preparatory 
Committee of the New Consultative Conference], in Wuxing hongqi cong zheli shengqi - Zhongguo remin zhengzhi xieshanghui dansheng 五星紅旗從這裡升起一 一中國人民政治協商會議誕生 (Beijing: Wenshi ziliao chubanshe, 1984), 282-284.

67 Qin Lihai, "1949 nian xin zhengxie choubei jishi," 6.

68 Ye Jiefu, "1949 nian xin zhengxie daibiao shi ruhe chansheng de," 45.

69 Roger B. Jeans, Democracy and Socialism in Republican China: The Politics of Zhang Junmai (Carsun Chang), 1906-1941 (Lanham: Rowman \& Littlefield, 1997), 305306.

70 Fang Qingqiu 方慶秋, Zhongguo minzhu shehuidang 中國民主社會黨 [Chinese Democratic Socialist Party] (Beijing: Dang'an chubanshe, 1988), 491-493.

71 Ye Jiefu, "1949 nian xin zhengxie daibiao shi ruhe chansheng de," 44; Peter Ivanov, "The Miscellany of China's Political Spectrum, 1945-1950," in Roads Not Taken: The Struggle of Opposition Parties in Twentieth Century China, ed. Roger B. Jeans (Boulder, CO: Westview Press, 1992), 171-188.

72 Liu Shaoqi, "Report from the Head of the Delegation of the $\mathrm{CC}$ of the Chinese Communist Party."

73 Ye Jiefu, "1949 nian xin zhengxie daibiao shi ruhe chansheng de," 44.

74 Duan Haiyan 段海燕, ed., Xianzhe buxiu: Lian Guan tongzhi jinian wenji 賢者不朽: 連貫同志紀念文集 [Virtuous Men Are Immortal: Commemorative Source Collection of Comrade Lian Guan] (Beijing: Zhongguo huaqiao chubanshe, 1995), 226-228.

75 Duan Haiyan, 213-229; Qin Lihai, "1949 nian xin zhengxie choubei jishi," 6.

76 Liu Shaoqi, "Report from the Head of the Delegation of the CC of the Chinese Communist Party."

77 Qin Lihai 秦立海, “Jianguo qian de ‘zuopai’ Zhang Bojun”建國前的「左派」章伯鈞 [The "Leftist" Zhang Bojun before the Founding of the People's Republic], Zhongshan fengyu 鍾山風雨, no. 3 (2010): 34-36.

78 Hua Sheng 華生, “Zhang Bojun mimi jiaru Zhonggong shuo” 章伯鈞秘密加入中共說 [Talks of Zhang Bojun Secretly Joining the Chinese Communist Party], Gongpingbao 公平報 1 , no. 2 (1947): 13.

79 See, for example, "Zhonggong mimi fabu dixia douzheng gangling" 中共秘密發布地下鬥爭綱領 [The Chinese Communist Party Is Secretly Issuing a Fighting Plan], Waijiaobu zhoukan 外交部週刊, no. 21 (1947): 1.

80 Liu Shaoqi, "Report from the Head of the Delegation of the CC of the Chinese Communist Party..

81 Mao Zedong 毛澤東, “Mao Zedong zai xin zhengxie huiyi choubeihui di yi ci quanti huiyi shang de jianghua” 毛澤東在新協商會第一次全體會議上的講話 [Mao Zedong's Speech at the First Plenary Session of the Preparatory Committee for the New Consultative Conference], in Wuxing hongqi cong zheli qi - Zhongguo remin zhengzhi xieshanghui dansheng 五星紅旗從這裡起一一國人民政治協商會議誕生, eds. Yang Jianxin 楊建新 and Shi Guangshu 石光樹 (Beijing: Wenshi ziliao chubanshe, 1984), 246-247.

82 Zhou Yiqing 周一青, Zhengxie zhishi yu shijian 政協知識與實踐 [Knowledge and Practice of the Consultative Conference] (Yuanjiang: Zhengxie Hunansheng Yuanjiangshi weiyuanhui, 1994), 123.

83 Shu Yun, "Zhengxie huiyi shang de quwen yishi," 169.

84 Guo Guilan 郭桂蘭, Zhongguo funü gemingshi 中國婦女革命史 [History of the Women's Revolution in China] (Harbin: Heilongjiang renmin chubanshe, 1988), 440.

85 See especially the issues from September 23 to 29 of the People's Daily (Renmin ribao 人民日報).

86 "Beiping Xinhua guangbo diantai jinwan guangbo renmin zhengxie si wu liangtian zhuyao fayan luyin” 北平新華廣播電台今晚廣播人民政協四五兩天主要發言錄音 [Beiping Broadcasting Station Broadcasts the Recordings of the Speeches Given on the 
Fourth and Fifth Day of the Chinese People's Consultative Conference], Renmin ribao 人民日報, September 26, 1949 .

87 Beetham, The Legitimation of Power, 12-13.

88 Sebastian Veg, "Propaganda and Pastiche: Visions of Mao in Founding of a Republic, Beginning of the Great Revival, and Let the Bullets Fly," China Perspectives, no. 2 (2012): 45.

89 Gloria Davies and M. E. Davies, “Filmed Founding Myths: 建國大業," China Heritage Quarterly, no. 20 (2009): 1-5.

90 Davies and Davies.

91 Ray Wang and Gerry Groot, "Who Represents? Xi Jinping's Grand United Front Work, Legitimation, Participation and Consultative Democracy," Journal of Contemporary China 27, no. 112 (2018): 569-583; "Shijiazhuang fabu 5 tiao hongse lüyou jingpin xianlu” 石家莊發布5條紅色旅遊精品線路 [Shijiazhuang Announces Five Premium Roads for Red Tourism], Xinhuawang 新華網, October 19, 2019, http://www.xinh uanet.com/local/2019-10/17/c_1125118144.htm.

\section{Bibliography}

Barnett, Doak. China on the Eve of the Communist Takeover. New York: Praeger, 1963.

Beetham, David. The Legitimation of Power. New York: Palgrave Macmillan, 2013.

"Beiping Xinhua guangbo diantai jinwan guangbo renmin zhengxie si wu liangtian zhuyao fayan luyin.” 北平新華廣播電台今晚廣播人民政協四五兩天主要發言錄音 [Beiping Broadcasting Station Broadcasts the Recordings of the Speeches Given on the Fourth and Fifth Day of the Chinese People's Consultative Conference]. Renmin ribao 人民日報, September 26, 1949 .

Brunner, Georg. "Legitimacy Doctrines and Legitimation Procedures in East European Systems." In Political Legitimation in Communist States, edited by Thomas Harold Rigby, and Ferenc Fehér, 27-44. Oxford: Macmillan: St. Antony’s College, 1982.

Cabestan, Jean-Pierre. "The Chinese People's Political Consultative Conference (CPPCC): Its Role and Its Future." In The EU-China Relationship - European Perspectives, edited by Kerry Brown, 51-62. London: Imperial College Press, 2015. https://doi.org/10.1142 /9781783264551_0005.

Culp, Robert. Articulating Citizenship: Civic Education and Student Politics in SouthEastern China, 1912-1940. Cambridge, MA: Harvard University Press, 2007.

Curran, Thomas D. Educational Reform in Republican China. Lewiston, NY: Edwin Mellen Press, 2005.

Davies, Gloria, and M. E. Davies. "Filmed Founding Myths: 建國大業.” China Heritage Quarterly 20 (2009): 1-5.

Dong, Biwu 董必武. Dong Biwu zhengzhi falü wenji 董必武政治法律文集 [Collected Political and Legal Works of Dong Biwu]. Beijing: Falü chubanshe, 1986.

Duan, Haiyan 段海燕, ed. Xianzhe buxiu: Lian Guan tongzhi jinian wenji 賢者不朽: 連貫同志紀念文集 [Virtuous Men Are Immortal: Commemorative Source Collection of Comrade Lian Guan]. Beijing: Zhongguo huaqiao chubanshe, 1995.

Duara, Prasenjit. Rescuing History from the Nation. Chicago, IL: University of Chicago Press, 1995.

Fang, Qingqiu 方慶秋. Zhongguo minzhu shehuidang 中國民主社會黨 [Chinese Democratic Socialist Party]. Beijing: Dang'an chubanshe, 1988.

Flood, Christopher. Political Myth: A Theoretical Introduction. London: Routledge, 2002. 
Fogel, Joshua A., and Peter Zarrow. Imagining the People. Armonk, NY: M. E. Sharpe, 1997.

Fung, Edmund S. K. "Recent Scholarship on the Minor Parties and Groups in Republican China." Modern China 20, no. 4 (1994): 478-508.

- In Search of Chinese Democracy: Civil Opposition in Nationalist China, 19291949. Cambridge Modern China Series. Cambridge: Cambridge University Press, 2000.

Geng, Yan. Mao's Images: Artists and China's 1949 Transition. Wiesbaden: J. B. Metzler, 2018.

Gerschewski, Johannes. "Legitimacy in Autocracies: Oxymoron or Essential Feature?" Perspectives on Politics 16, no. 3 (2018): 652-665.

Groot, Gerry. Managing Transitions: The Chinese Communist Party, United Front Work, Corporatism, and Hegemony. New York: Routledge, 2004.

Guo, Guilan 郭桂蘭. Zhongguo funü gemingshi 中國婦女革命史 [History of the Women's Revolution in China]. Harbin: Heilongjiang renmin chubanshe, 1988.

Hill, Joshua. Voting as a Rite: A History of Elections in Modern China. Cambridge: Harvard University Press, 2019.

Hua, Sheng 華生. “Zhang Bojun mimi jiaru Zhonggong shuo” 章伯鈞秘密加入中共說 [Talks of Zhang Bojun Secretly Joining the Chinese Communist Party]. Gongpingbao 公平報 1, 2 (1947): 13.

Ivanov, Peter. "The Miscellany of China's Political Spectrum, 1945-1950." In Roads Not Taken: The Struggle of Opposition Parties in Twentieth Century China, edited by Roger B. Jeans, 171-188. Boulder: Westview Press, 1992.

Jeans, Roger B. Democracy and Socialism in Republican China: The Politics of Zhang Junmai (Carsun Chang), 1906-1941. Lanham: Rowman \& Littlefield, 1997.

Levenson, Joseph. Confucian China and Its Modern Fate. Berkeley: University of California Press, 1968.

Li, Ge 李格. “Yi jie zhengxie choubei wenti de ruogan kaocha”一屆政協籌備問題的若 干考察 [Investigation into the Preparations for the Political Consultative Conference]. Dangdai Zhongguo shi yanjiu 當代中國史研究 13, no. 4 (2006): 71-76.

Li, Jishen 李濟深. “Zhongguo guomindang geming weiyuanhui - Duiyu xin zhengxie de yijian” 中國國民黨革命委員會一一對於新政協的意見 [The Revolutionary Committee of the Chinese Guomindang - Views on the New Consultative Conference]. Ziyou 自由, no. 8 (1948): 20-21.

—. 李濟深. "Yonghu Zhonggong baxiang tiaojian: Renmin minzhu geming bixu jinxing daodi” 擁護中共八項條件: 人民民主革命必須進行到底 [In Support of the Eight Demands of the Communist Party - The People's Democratic Revolution Has to Be Carried Through to the End]. Gonglun 公論 5 (1949): 21-22.

"Li Jishen Shen Junru Zhang Bojun deng fabiao shiju yijian" 李濟深沈鈞儒章伯鈞等發表時局意見 [Li Jishen, Shen Junru, and Zhang Bojun Express Their Views on the Current Political Situation]. Haitao 海濤 5 (1949): 14.

Li, Peijin 李沛金. Wo de fuqin Li Jishen 我的父親李濟深 [My Father Li Jishen]. Beijing: Tuanjie chubanshe, 2007.

Liu, Shaoqi. "Report from the Head of the Delegation of the CC of the Chinese Communist Party, "The Current State of the Chinese Revolution."' Translated by Gary Goldberg. RGASPI, f. 558, op. 11, d. 328, 11. 32-50. History and Public Policy Program Digital Archive, July 4, 1949. https://digitalarchive.wilsoncenter.org/docum ent/134156

Liu, Yandong 劉延東, ed. Lishi cong zheli kaishi - Jinian Zhongguo Gongchandang lingdao de duodang hezuo wu shi zhou nian 歷史從這裡開始——紀念中國共產黨 
領導的多黨合作五十週年 [This Is Where the History Begins - Commemorating the 50th Anniversary of the Chinese Communist Parties' Multi-Party Cooperation]. Beijing: Huawen chubanshe, 1999.

Luo, Jianbai 羅堅白. “Guoshedang ruci ‘zai fenlie’”國社黨如此「再分裂」[So the National Socialist Party Is Divided Again]. In Zhongguo minzhu shehuidang 中國民主社會黨 [Chinese Democratic Socialist Party], edited by Fang Qingqiu 方慶秋, 499-508. Beijing: Dang'an chubanshe, 1988.

Mao, Zedong. "Cable, Mao Zedong to Stalin." Translated by Sergey Radchenko. APRF: F. 39, Op. 1, D. 31, L1. 49-52. History and Public Policy Program Digital Archive, December 30, 1948. https://digitalarchive.wilsoncenter.org/document/113789

毛澤東. “Lun renmin minzhu zhuanzheng”論人民民主專政 [On the People's Democratic Dictatorship]. In Lun renmin minzhu zhuanzheng xuexi cankao cailiao 論人民民主專政學習參考材料 [Study Materials on the People's Democratic Dictatorship], edited by Duzhe shudian 讀者書店, 1-12. Tianjin: Duzhe shudian, 1949.

"Mao Zedong zai xin zhengxie huiyi choubeihui di yi ci quanti huiyi shang de jianghua” 毛澤東在新協商會第一次全體會議上的講話 [Mao Zedong's Speech at the First Plenary Session of the Preparatory Committee for the New Consultative Conference]. In Wuxing hongqi cong zheli qi - Zhongguo remin zhengzhi xieshanghui dansheng 五星紅旗從這裡起——中國人民政治協商會議誕生 [From Here the Red Five-Star Flag Rose - The Birth of the Chinese Political Consultative Conference], edited by Yang Jianxin 楊建新 and Shi Guangshu 石光樹, 246-247. Beijing: Wenshi ziliao chubanshe, 1984.

. "Mao Zedong guanyu zhaokai xin zhengxie fu ge minzhu dangpai dian" 毛澤東關於召開新政協復各民主黨派電 [Telegram by Mao Zedong to the Minor Political Parties and Groups on Convening a New Consultative Conference]. In Zhonggong zhongyang wenjian xuanji 中共中央文件選集 [Selected Documents of the Central Committee of the Chinese Communist Party], edited by Zhongyang dang'anguan 中央檔案館, 273-274. 17 (1948). Beijing: Zhonggong zhongyang dangxiao chubanshe, 1992.

Mikoyan, Anastas Ivanovich. "Memorandum of Conversation between Anastas Mikoyan and Mao Zedong." Translated by Sergey Radchenko. APRF: F. 39, Op. 1, D. 39, L1. 7-16. History and Public Policy Program Digital Archive, January 31, 1949. https://di gitalarchive.wilsoncenter.org/document/112436.

Peng, Juyuan 彭菊園. “Ping guomin canzhenghui” 評國民參政會 [Assessing the National Political Participatory Assembly]. Minzhu 民主 1, no. 1 (1938): 20-21.

Qin, Lihai 秦立海. “1949 nian xin zhengxie choubei jishi”1949年新政協籌備紀事 [Record of the Preparatory Work for the New Consultative Conference of 1949]. Wenshi jinghua 文史精華 183 (2000): 4-11.

- “ “Jianguo qian de 'zuopai' Zhang Bojun”建國前的「左派」章伯鈞 [The "Leftist" Zhang Bojun Before the Founding of the People's Republic]. Zhongshan fengyu 鍾山風雨 3 (2010): 34-36.

Rahav, Shakhar. "Predicated on the People: Legitimating Mass Politics and Parties in Early Republican China." Cross-Currents: East Asian History and Culture Review 6, no. 1 (2017): 262-295.

Renmin zhengxie wang 人民政協網. “Ba ge minzhu dangpai de paixu shi ruhe queding de" 八個民主黨派的排序是如何確定的 [How the Sorting Order of the Eight Democratic Parties and Groups Was Determined], February 2, 2016. http://www.rmzxb.com.cn/c /2016-02-15/697897.shtml 
Rosa, Ruth Amende. "The Soviet Theory of 'People's Democracy'." World Politics 1, no. 4 (1949): 489-510.

Ruo, Yu 若愚. “Cong jiantao Guo Gong huitan jiyao shuodao zhengzhi xieshang huiyi de qiantu” 從檢討國共會談紀要說到政治協商會議的前途 [Discussing the Future of the Consultative Conference in Light of the Minutes of the GMD-CCP Talks]. Minzhu 民主5 (1946): 1 .

Schwartz, Benjamin. "China and the Soviet Theory of People's Democracy." Problems of Communism 3, no. 5 (1954): 8-15.

Seymour, James D. "China's Satellite Parties Today." Asian Survey 26, no. 9 (1986): 991-1004.

Sha, Jiansun 沙建孫, ed. Zhongguo gongchandang tongshi 中國共產黨通史 [Comprehensive History of the Chinese Communist Party]. Vol. 5. Changsha: Hunan jiaoyu chubanshe, 2000.

Shaanxi zhengjiaoxi bianxiezu 陝西師大政教系編寫組, ed. Zhongguo Gongchandang lishi 中國共產黨歷史 [History of the Chinese Communist Party]. Chang'an: Shaanxi shida zhengjiaoxi, 1980.

Shen, Junru 沈鈞儒. “Wo duiyu shiju kanfa” 我對於時局看法 [My Views on the Current Political Situation]. Shidai piping 時代批評 5, no. 104 (1948): 7.

Shen, Junru 沈鈞儒 and Zhang Bojun 章伯鈞. “Shiju shengming” 時局聲明 [Statement on the Current Political Situation]. Guangmingbao 光明報 2, no. 8 (1948): 2.

Shu, Yun 舒雲. “Zhengxie huiyi shang de quwen yishi” 政協會議上的趣聞軼事 [Interesting Anecdotes from the Consultative Conference]. In Jianguo milu 建國秘錄, edited by Cao Ying 曹英 and Yu Minhui 余敏輝, 153-174. Beijing: Tuanjie chubanshe, 1993.

Skilling, H. Gordon. "People's Democracy, the Proletarian Dictatorship and the Czechoslovak Path to Socialism." American Slavic and East European Review 10, no. 2 (1951): 100-116.

Slyke, Lyman van. Enemies and Friends: The United Front in Chinese Communist History. Stanford, CA: Stanford University Press, 1967.

Sullivan, Walter. "China's Communists Set Stage to Form Coalition Regime.” New York Times, June 20, 1949.

Sun, Qimeng 孫起孟. “Ha’erbinshi jianyu canguanji” 哈爾濱市監獄參觀記 [Notes from a Visit to the Harbin Municipal Prison]. Jinbu qingnian 進步青年 1 (1949): 26-27, 31. . “Wo duiyu zhishi fenzi gaizao de jidian renshi” 我對於知識分子改造的幾點認識 [Some Remarks on My Understanding of Reforming the Intellectuals]. Jinbu qingnian 進步青年 2 (1949): 5-7.

Sun, Xiaohua 孫䁱華 and Sun Shizhong 宋士忠, eds. Fengyu tongzhou gandanqing 風雨同舟肝膽情 [A Heroic Spirit Through Thick and Thin]. Beijing: Zhonggong zhongyang dangxiao chubanshe, 1995.

Tao, Xingzhi 陶行知. “Guonan huiyi yu mingren huiyi” 國難會議與名人會議 [The National Emergency Conference and the Celebrity Conference]. Shenbao 申報, January 28, 1932, 11.

Teiwes, Frederick C. Leadership, Legitimacy, and Conflict in China: From a Charismatic Mao to the Politics of Succession. Armonk, NY: M. E. Sharpe, 1984.

Tong, Xiaopeng 童小鵬, $\mathrm{Yu}$ Gang 于剛, and Yin Hua 尹華. “Guanyu choubei he zhaokai Zhongguo renmin zhengzhi xieshang huiyi de huiyi" 關於籌備和召開中國人民政治協商會議的回憶 [Recollection of the Preparations and Convening of the Chinese People's Political Consultative Conference]. In Yinglai 
shuguang de shenghui - Xin zhengzhi xieshang huiyi qin liji 迎來曙光的盛會 新政治協商會議親歷記 [Greeting a Dawning Great Gathering - Personal Memories of the New Consultative Conference], edited by Shi Guangshu 石光樹, 1-25. Beijing: Zhongguo wenshi chubanshe, 1987.

Veg, Sebastian. "Propaganda and Pastiche: Visions of Mao in Founding of a Republic, Beginning of the Great Revival, and Let the Bullets Fly." China Perspectives 2 (2012): 41-53.

Wang, Ray, and Gerry Groot. "Who Represents? Xi Jinping's Grand United Front Work, Legitimation, Participation and Consultative Democracy." Journal of Contemporary China 27, no. 112 (2018): 569-583. https://doi.org/10.1080/10670564.2018.1433573.

Weber, Max. Economy and Society. Berkeley: University of California Press, 1987.

Wei, Liang 維梁. "Rushi wo wen de xin zhengxie ji daji xin zhengxie de fangce" 如是我聞的新政協及打擊新政協的方策 [What I Heard of the New Consultative Conference and the Measures Taken Against the New Consultative Conference]. Shenghuo yu shidai 生活與時代 1, no. 6 (1948): 9.

Xinhuashe 新華社. Jiang geming jinxing daodi 將革命進行到底 [Carry the Revolution through to the End]. Beijing: Xinhua shuju, 1949.

Xinhuawang 新華網. "Shijiazhuang fabu 5 tiao hongse lüyou jingpin xianlu" 石家莊發布5條紅色旅遊精品線路 [Shijiazhuang Announces Five Premium Roads for Red Tourism], October 19, 2019. http://www.xinhuanet.com/local/2019-10/17/c_1 125118144.htm.

Yang, Jianxin 楊建新 and Shi Guangshu 石光樹, eds. “Guanyu canjia xin zhengzhi xieshang huiyi de danwei ji qi daibiao ming'e de guiding" 關於參加新政治協商會議的單位及其代表名額的規定 [On the Regulations Concerning the Groups and Their Quota of Representatives to the Preparatory Committee of the New Consultative Conference]. In Wuxing hongqi cong zheli shengqi - Zhongguo remin zhengzhi xieshanghui dansheng 五星紅旗從這裡升起一 一中國人民政治協商會議誕生 [From Here the Red Five-Star Flag Rose - The Birth of the Chinese Political Consultative Conference], 282-284. Beijing: Wenshi ziliao chubanshe, 1984.

, eds. "Guanyu zhaokai xin de zhengzhi xieshang huiyi wenti de xieyi" 關於召開新的政治協商會議問題的協議 [Agreement on Questions Concerning the Convening of a New Consultative Conference]. In Wuxing hongqi cong zheli shengqi - Zhongguo remin zhengzhi xieshanghui dansheng 五星紅旗從這裡升起— 一中國人民政治協商會議誕生 [From Here the Red Five-Star Flag Rose - The Birth of the Chinese Political Consultative Conference], 212-14. Beijing: Wenshi ziliao chubanshe, 1984.

Ye, Jiefu 葉介甫. “1949 nian xin zhengxie daibiao shi ruhe chansheng de" 1949年新政協代表是如何產生的 [How the New Political Consultative Conference's Delegates Were Nominated in 1949]. Yanhuang chunqiu 炎黃春秋 6 (2019): 41-45.

Yu, Yuan 于遠. “Miluo jingu de xin zhengxie” 密鑼緊鼓地新政協 [The Beating of Gongs and Drums for the New Political Consultative Conference]. Xin zhengzhijia 新政治家 1, no. 4 (1948): 3-6.

Zarrow, Peter. After Empire: The Conceptual Transformation of the Chinese State, 18851924. Stanford, CA: Stanford University Press, 2012.

Zhang Xin 張昕. “Ba ge minzhu dangpai paixu de youlai” 八個民主黨派排序的由來 [The Origins of the Sorting Order of the Eight Democratic Parties and Groups]. Shidai youkan 時代郵刊 7 (2019): 24-25. 


\section{Henrike Rudolph}

“Zhonggong mimi fabu dixia douzheng gangling” 中共秘密發布地下鬥爭綱領 [The Chinese Communist Party Is Secretly Issuing a Fighting Plan]. Waijiaobu zhoukan 外交部週刊 21 (1947): 1.

Zhongguo minzhu tongmeng zhongyang wenshi ziliao weiyuanhui 中國民主同盟中央文史資料委員會, ed. Zhongguo minzhu tongmeng lishi wenxian 1941-1949 中國民主同盟歷史文獻1941-1949 [Historical Documents of the Chinese Democratic League 1941-1949]. Beijing: Wenshi ziliao chubanshe, 1983.

Zhou, Yiqing 周一青. Zhengxie zhishi yu shijian 政協知識與實踐 [Knowledge and Practice of the Consultative Conference]. Yuanjiang: Zhengxie Hunansheng Yuanjiangshi weiyuanhui, 1994. 